\title{
Partnerships for Knowledge Building: An Emerging Model
}

\section{Partenariats pour la coélaboration de connaissances : un modèle en émergence}

Thérèse Laferrière, Mireia Montané, Begona Gros, Isabel Alvarez, Merce Bernaus, Alain

Breuleux, Stéphane Allaire, Christine Hamel, and Mary Lamon

\author{
Authors \\ Thérèse Laferrière, Professor, Faculty of Education, Laval University, Québec, QC, Canada. \\ Correspondence regarding this article can be sent to tlaf@fse.ulaval.ca \\ Mireia Montané, Ministry of Education, Catalunya, Spain \\ Begona Gros , University of Barcelona, Spain \\ Isabel Alvarez, University Autonome of Barcelona, Spain \\ Merce Bernaus, University Autonome of Barcelona, Spain \\ Alain Breuleux, McGill University, Quebec \\ Stéphane Allaire, Université du Québec à Chicoutimi, Québec \\ Christine Hamel, Laval University, Québec \\ Mary Lamon, Lamon Consulting, Toronto, Ontario
}

\section{Abstract}

Knowledge Building is approached in this study from an organizational perspective, with a focus on the nature of school-university-government partnerships to support researchbased educational innovation. The paper starts with an overview of what is known about effective partnerships and elaborates a conceptual framework for Knowledge Building partnerships based on a review of literature and two case studies of school-universitygovernment partnerships. In one case, a Ministry of Education wanted to bring more vitality into schools of small remote villages, and in the other case another Ministry of Education wanted to renew its school-based international cooperation profile. Emerging from this work is a three-component model for going to scale with Knowledge Building partnerships: Knowledge Building as a shared vision; symmetric knowledge advancement; and multi-level, research-based innovation. Characteristics of, and conditions for, effective partnerships for Knowledge Building are elaborated, and an emerging model is developed to help communities establish effective partnerships and contribute to this evolving model.

\section{Résumé}

La coélaboration de connaissances est étudiée dans une perspective organisationnelle en mettant l'accent sur la nature des partenariats entre l'école, l'université et le 
gouvernement afin de soutenir l'innovation en éducation. L'article présente un aperçu de ce qui est connu des partenariats qui fonctionnent et il élabore un cadre conceptuel portant sur les partenariats en coélaboration de connaissances basé sur une analyse documentaire et deux cas de partenariats. Dans le premier cas, le ministère de l'Éducation voulait dynamiser des écoles de petits villages éloignés, et dans le deuxième cas, un autre ministère de l'Éducation souhaitait renouveler le profil coopératif international d'une école. Ce qui ressort de cette étude est un modèle en trois parties : la coélaboration de connaissances en tant que vision partagée, l'avancement symétrique des connaissances et l'innovation à niveaux multiples fondée sur la recherche. Les caractéristiques et les conditions pour des partenariats efficaces sont donc développées, et un nouveau modèle émergent est proposé pour aider les communautés à établir des partenariats gagnants et à contribuer à ce modèle en évolution.

\section{Partnerships for Knowledge Building: An Emerging Model}

Knowledge Building is a collaborative effort directed towards creating and improving ideas. Ideally, ideas get out into the whole community in a form that allows the community to identify problems of understanding, to gather and critique information from authoritative sources, and to create theories, explanations, historical accounts, novel problem formulations, and solutions. Can schools operate as knowledge-creating organizations or are they bound to their role as knowledge-telling organizations? Researchers within the Institute for Knowledge Innovation and Technology (www.ikit.org) are addressing that question; the work reported here is part of that larger effort.

Knowledge Building is a powerful vision of what can happen in today's classrooms. It is a vision that has captured the imagination of social and educational leaders who foresaw its potential for preparing twenty-first century workers and citizens. The need for social and technological innovation to foster educational reform is generally becoming understood. However, combining education reform with new information and communication technology is demanding and complex. The technology provides rich learning environments, as envisioned by reformers, yet the power of the technology can only be realized with new ideas at the center of the curriculum (Lamon, Laferrière, \& Scardamalia, 2005). For Knowledge Building innovations this requires teachers who can design knowledge-creating organizations in classrooms using emerging devices, tools, media, and virtual environments. These multifaceted, multi-level challenges require collaborative research and involvement of government representatives to provide professional development opportunities and practices to ensure accountability (also see Hartnell-Young, 2009).

Effective partnership arrangements and ways to foster them remain to be explored (e.g., Fishman, Marx, Blumenfeld, \& Krajcik, 2004). Here, we focus on the dynamics of partnerships that take advantage of technology to create classroom-based Knowledge Building communities as well as globally distributed knowledge-creating organizations. We present two case studies that make use of a Knowledge Building environment, Knowledge Forum ${ }^{\circledR}$, to foster 
partnerships $^{1}$. The work is situated in the Knowledge Society Network, hosted by the Institute for Knowledge Innovation and Technology (also see Hong, Scardamalia, \& Zhang, present issue; also see http://ikit.org/ksn.html). This network integrates researchers and practitioners in over 20 countries committed to research-based innovation in education.

This paper presents a conceptual/analytical framework that builds upon what is known regarding school innovation and partnerships and presents two case studies of schooluniversity-government partnerships. These convergent efforts point to an emerging model of partnerships to support educational innovation. Our goal is to elaborate conditions that might help other teams establish effective partnerships and possibly join the Knowledge Society Network - a community of communities aiming to maximize society's Knowledge Building capacity.

\section{School innovation and partnerships: A literature review}

\section{Socio-cognitive-technology innovations}

The research framework on systemic technology innovations suggested by Fishman et al. (2004) emphasizes cognitively-oriented technology innovations, that is, ones "designed to foster deep thinking and learning" (p. 43). However, many of those who champion information and communication technology (ICT) deployment in schools and classrooms do not have the "cognitively-oriented" component in mind. This is reflected in the fact that, even when there is access to Internet-connected computers, teachers do not necessarily provide opportunities for students to learn with them. For instance, in Canada, ICT is available at a high level; but use by school learners during class time remains low (OECD, 2006) ${ }^{2}$. Another issue is how the time using the computer is spent during class time.

The extent to which a teacher holds a constructivist orientation has been found to be a second factor influencing whether students can access the Internet during class time (Becker \& Riel, 1999). Constructivist teachers recognize that everyone constructs meaning; not just the teacher or expert. Therefore, such teachers are more inclined to engage students in Web-based inquiries and online collaborative activities. A third factor that teachers often mention in surveys of computer use is time ${ }^{3}$. The working hypothesis here is that teachers who do not see a close connection between the use of Internet-based technologies and the curriculum are unlikely to "give time away" to students.

On university campuses, teacher educators must find ways for pre-service teachers to be educated in how to use ICT for teaching and learning (Resta, in press; UNESCO, 2003, 2008). One effective use of ICT is to support communication and collaboration in both onsite and online environments. "Socialware" is an often-used term to designate computer tools that

${ }^{2}$ Information and communication technology use is found to be high in countries such as Hungary that emphasize the learning of informatics.

${ }^{2}$ Information and communication technology use is found to be high in countries such as Hungary that emphasize the learning of informatics.

Here are examples of the questions asked in the PISA study on which the 2006 OECD report was based: Who taught you most about how to use the Internet? How often do you use The Internet to look up information about people, things or ideas? How often do you use the Internet to collaborate with a group or team? (pp. 157-159). 
support these kinds of communication among users.

We focus in this discussion on a particular form of socio-cognitive software. The Institute for Knowledge Innovation and Technology/Knowledge Society Network team has created software specially designed to support knowledge-creating organizations. To support these organizations it is necessary to coordinate the work of widely distributed teams, engage participants throughout the network in the process of knowledge innovation, and provide effective means to support continual idea improvement (Scardamalia \& Bereiter, 2006; Scardamalia, Bransford, Kozma, \& Quellmalz, in press). The focus on research-based innovation is further supported through a suite of analytic tools that underlie Knowledge Forum. These provide support for an ever-growing array of assessment tools, including tools that show profiles of individual and group growth in writing, vocabulary, and other indications of knowledge advancement and patterns of participant interaction. Scardamalia and Bereiter (1996) stress the connection between the solving of knowledge problems, ones linked to the curriculum, and use of the technology-mediated Knowledge Building environment. Knowledge Forum is the result of more than two decades of analysis of the process of expertise and innovation, involving cognitive and computer scientists and practitioners, with social innovation (Knowledge Building) and technology innovation (Knowledge Forum) reciprocally linked and both central to the classroom agenda. Throughout the years the environment has been refined through use, in schools, elementary to tertiary levels, health care and community organizations, businesses, and so forth.

Within school contexts students, teachers, and principals as well as school-district support personnel, university students, researchers, and engineers all play a role. In larger collaborations, government agencies and/or businesses may become important partners, through co-design, use, and continual improvement of an environment. It is in this sense that it represents a model of "socio-cognitive-technology" innovations.

\section{Multi-institutional collaboration as social innovation}

The strategy of establishing school-university partnerships has been promoted in the educational field (Goodlad, 1990; Holmes Group, 1990; NCATE, 2001) as an innovative solution for improving what is going on in the classroom. In the United States, this strategy led to the design of professional development schools (Holmes Group, 1990). A professional development school was meant to be a new organization for educational researchers and practitioners to cultivate a shared vision of classroom improvement, be it an elementary, secondary, or tertiary classroom (teacher education). As education faculties designed professional development schools, they sought to integrate the three dimensions that connect them to schools: preservice teachers' early field experiences and practice teaching, in-service teachers' professional development, and collaborative research. However, such partnerships were found to be hard to sustain and difficult to scale up, given local dynamics and contexts (Bullough et al., 1999; Clark, 1999; Levine \& Tratchman, 1997; McBee \& Moss, 2002; Sykes, 1997; Teitel, 1997, 2001).

In Canada, The TeleLearning Network of Centres of Excellence built university-school partnerships at four sites (Vancouver, Toronto, Montreal, and Quebec City) in an effort to 
reduce the divide between the research and practice cultures (Bereiter, 2002). Internet-based tools supported communication and collaboration within and between sites. These universityschool partnerships were key for design of, and research on, uses of ICT in teacher education and teacher professional development (Breuleux, Erickson, Laferrière, \& Lamon, 2002).

Three-way partnerships involving business or government can be even more challenging than school-university partnerships. The literature on partnerships emphasizes the importance of converging visions and strategies (Bringle \& Hatcher, 2002; Legters, Balfanz, \& McPartland, 2002). Our assumption is that a partnership's foundation depends on a big idea, one capable of driving the collaborative effort of educators based in different institutions. Knowledge Building applied to elementary and secondary schools is such an idea. Partners use Knowledge Forum as a "collaborative space" with school learners, and among themselves. Together, they create a network dedicated to Knowledge Building, namely the Knowledge Society Network.

\section{Two case studies of school-university-government partnerships}

For technological, social, or curricular innovation to reach the classroom, top-down and bottomup movement (the vertical dynamic) is necessary (Bates, 2000; Kenny, 2003). Also see Fullan's (2000) three stories of education reform (the inside story, the inside-outside story, the outsidein story). It is our understanding that, for innovation to occur, lateral movement (the horizontal dynamic) is also important between leaders and members of school-university-government partnerships. From previous studies on partnership development (Ertmer \& Hruskocy, 1999; Fishman et al., 2004; Laferrière, Breuleux, \& Erickson, 2007; Sandholtz, 2002) and participation within the Knowledge Society Network, we retained three dynamic characteristics for further collaborative inquiry into Knowledge Building partnerships: Knowledge Building as a shared vision, symmetric knowledge advancement, and multi-level, research-based innovation.

\section{Knowledge Building as a shared vision}

Our understanding of a shared vision is one that is cultivated by the leaders and members of a given organization through an iterative process. A shared vision is to be refined and advanced. For instance, teachers' entry-level concerns regarding the establishment of a Knowledge Building community may be epistemological, pedagogical, or technological (Lamon \& Laferrière, 2004). As teachers address their entry-level concerns and later move to address other types of concerns, they uncover how Knowledge Building may be enacted in a classroom. By sharing their understanding of a Knowledge Building community and its enactment with colleagues and organizational leaders they contribute to the refinement and advancement of the shared vision. The Knowledge Society Network is the reference organization through which Knowledge Building as a practice is best understood and enacted; researchers and practitioners' from different cultures (Bereiter, 2002) converge to improve the classroom by transforming it into a Knowledge Building community (Bereiter \& Scardamalia, 1989, 1993). Conceptual tools such as the Knowledge Building principles (Scardamalia \& Bereiter, 2003) and the Knowledge Forum suite of ICT tools support these Knowledge Building communities.

\section{Symmetric knowledge advancement}


The socio-cognitive dynamics of this principle, as defined by Scardamalia (2002) are: "Expertise is distributed within and between communities. Symmetry in knowledge advancement results from knowledge exchange and from the fact that to give knowledge is to get knowledge." ( $p$. 80) In the cases of this report, the giving and getting of knowledge operates both within and across homogeneous groups such as school students, pre-service teachers, teachers, teacher educators, cognitive science researchers, and government education officials, and is beginning to extend across cultures and countries. Having Knowledge Forum, as a common discourse technology, facilitates sharing of diverse expertise both within and across groups.

Teachers, technology experts, instruction and curriculum experts, school principals, cognitive science researchers, and students are all important for continual improvement of one's understanding and enactment of the Knowledge Building communities discussed in this report. For instance, it may be a student teacher who knows about Knowledge Forum who presents the Knowledge Building principles to a teacher, or a classroom teacher who coaches another classroom teacher, or a graduate student feeding back data analysis to a Knowledge Building community, or young students serving as mentor to other students (McAuley, 2009), or a cognitive scientist interviewed about Knowledge Building and conveying ideas to an emerging Knowledge Building community. Through these and a variety of means collaborative problem solving leads to symmetric knowledge advances in a successful Knowledge Building partnership.

\section{Multi-level, research-based innovation}

Local grounding as well as participation in a worldwide network requires sustained engagement on the part of the partners with the goal of transforming local classrooms and schools into Knowledge Building communities. There are face-to-face meetings and, in best cases, they extend online. Ideas are not only being shared but improved. Individual teachers and school principals have contributed to results reported in the Knowledge Society Network and have published papers. As other members know their teaching or research, they influence one another and the network expands. The Knowledge Society Network has thus come to include a broad range of networked Knowledge Building communities, including teams from early to advanced stages of implementation (Hong et al., present issue; Scardamalia, 2003).

In the remainder of this paper, the above partnership dynamics (see Figure 1), as realized in two contrasting cases, are elaborated, and constituents of an emerging model identified. 


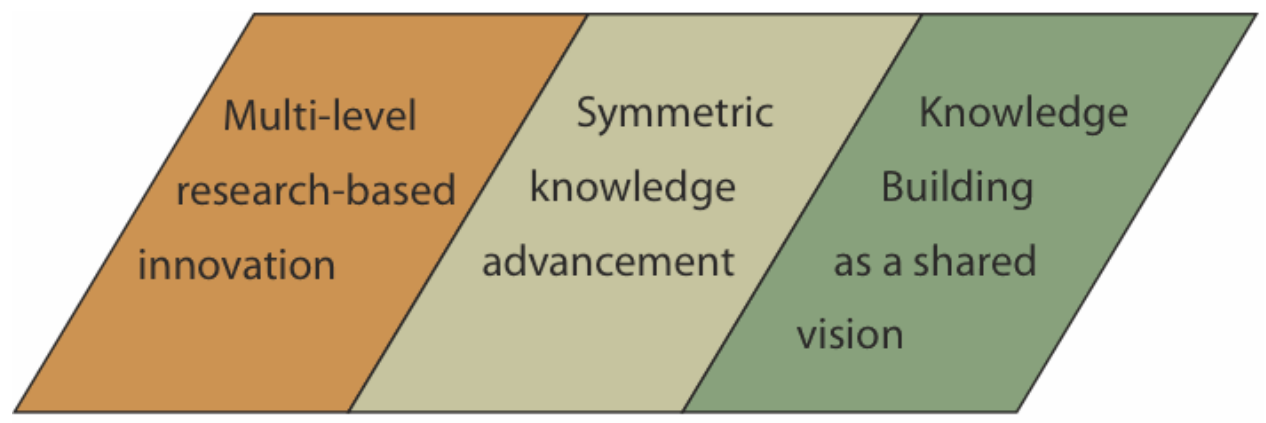

Social and Technological Innovation

Figure 1: The dynamics of partnerships for classroom-based Knowledge Building

\section{Method}

\section{Design similarities}

Design conversations (Banathy, 1991) occurred between potential partners, and a shared vision began to take shape. University-based teacher educators and researchers from two culturally different sites engaged, each with the support of their provincial government, in collaborative research with schools interested in Internet-enabled activity (multi-level, research-based innovation). Socio-cognitive-technology innovations were favoured by the university and government partners. Work proceeded on the basis of authentic and real problems including teachers' interpretations of the intended curriculum or local context and students' interests and inquiries regarding the curricular matters. Knowledge Forum was suggested as the most suitable technology by the university-based researchers. For two years, teachers at the two sites became familiar with the Knowledge Building principles (Scardamalia \& Bereiter, 2003) and the Knowledge Forum suite of tools, and used them with students in their own classrooms. Beginners used Knowledge Forum in the basic mode (notes, movies, attachments, and views are presented in list format), and more advanced users used the enhanced mode to place their notes in the shared space and draw pictures in view windows as backgrounds. The Knowledge Building principles, the Knowledge Forum software, and related tools (user's manual, scaffolds, virtual tours) were translated into French and/or Catalan.

Scaffolds within Knowledge Forum orient learners toward specific cognitive and metacognitive activity. The basic Knowledge Building set of scaffolds for theory development was used, with the following specific supports: My theory, I need to understand, New information, This theory cannot explain, A better theory, and Putting our knowledge together. Virtual tours are multimedia accounts of the evolution of exemplary knowledge-building communities. Virtual practica are online learning activities designed around virtual tours, and with goals tailored to teachers' and student teachers' needs and interests. Virtual practica were offered as a way of planning for innovation in the classroom (Laferrière, 2003; Laferrière, Lamon, \& Allaire, 2005). At both sites, a number of participants engaged in collaborative reflective practice using Knowledge Forum for their own professional development and developed perspectives within specific databases. 


\section{Participants}

In Case Study One (2004-2009) the provincial Department of Education (Catalunya, Spain), two universities and ten individual schools were partner institutions. The Ministry of Education funded the initiative aimed at the renewal of its school-based international cooperation profile. Fifteen volunteer urban-school teachers, including ones with previous experience in networking their classroom with other European classrooms, made use of Knowledge Forum and the Knowledge Building principles. At this site, the number of students per classroom averaged twenty-five same-age students.

In Case Study Two (2004-2009) the provincial Department of Education (Quebec, Canada), three universities, and thirteen pilot sites (50 remote rural schools) were partner institutions. The Ministry of Education funded the initiative aimed at bringing more vitality into schools of small remote villages. Most of the classrooms were multi-age classrooms and the number of students per classroom ranged from 5 to 20 students per classroom. Over 100 teachers with very little or no experience with networking their classrooms with other classrooms volunteered to participate in the initiative.

\section{Data gathering and analysis}

In each of the two cases, local university research teams gathered data in and outside the classroom (micro and meso levels). At the micro level they studied classroom discourse by analyzing Knowledge Forum databases using the Analytic Toolkit for quantitative analysis (Allaire et al. 2006; Consell Superior d'Avaluacio, 2006). At the qualitative level, the presence of explanation in students' contributions was one of the indicators of progress analyzed (CroteauBouffard, 2007).

At the meso or organizational level, data was gathered on the unfolding of the partnership structure and activity using questionnaires and ethnographic methods. Organizational documents (school district technology and strategic plans, school educational plans, and specific policies, projects or reports) were gathered. Interviews with a subset of participants (teachers, school principals, students, technology and curriculum experts, and school district administrators) were conducted, transcribed, and analyzed. Onsite/online participant observation allowed a closer look at vertical/lateral movements between innovation partners. Online participant observation was conducted in Quebec through the initiation of, or attendance at, teleconference (phone or video) meetings (oral discourse) or looking into Barcelona and Quebec teacher/educator databases (written discourse).

Grounded theory (Strauss \& Corbin, 1998) was applied for categorizing data according to participants' workplaces and their interactions with one another. Events and related circumstances were classified and the interpretation of the data led to the identification of themes and patterns (Moustakas, 1990) reflective of specific characteristics and indicative of the following four dynamics: Knowledge Building as a shared vision, diversity of expertise, local/global participation, and multi-level innovation. Further conceptualization led to a reorganization of themes and patterns and more abstraction. The three dynamic characteristics presented earlier in this paper stood out: Knowledge Building as a shared vision; symmetric 
knowledge advancement; and multi-level, research-based innovation. Results from the two cases are presented according to these three dynamics, which provide conditions for schooluniversity-government partnerships and research-based educational innovation.

\section{Results}

\section{Case Study One}

\section{Knowledge Building as a shared vision}

Laferrière, a university researcher, initially presented the vision of a Knowledge Building partnership to governmental agency director, Montané, Generalitat de Catalunya. Design conversations about new technologies and their contribution to education, and the affordances of Knowledge Building and Knowledge Forum took place with Montané and other governmental colleagues; other university researchers and government directors were interested and a proposal was written. The initiative received support from a number of local influential educators, and was submitted to the Minister of Education who saw it as a means to achieve already set goals for innovative approaches to technology integration into classrooms and schools. "We want the participants to act as transformative agents in the schools, disseminating

a way of work different from the traditional one, more coherent with the requirements of the knowledge society" (Generalitat de Catalunya, 2005, p. 2). Funding was secured, and urban school recruitment began.

Knowledge Building as a shared vision for school innovation entered a second cycle, and reasons for change and innovation were explained as well as ways in which Knowledge Building was to contribute to the renewal of pedagogy of volunteer school principals and teachers. Teacher leaders, and some school principals, became advocates, and classroom artifacts had a positive and powerful effect on other school principals, teachers, government agents, and parents.

\section{Symmetric knowledge advancement}

The governmental agency had rallied expertise from its social network, including school teachers and principals with whom international projects had been conducted in the past. For such international projects teachers had relied on material resources and regular mail and, in some instances, telematics. Similarly, a number of school students had been previously exposed to the leading-edge pedagogies within their cultural context. Other experts, including technology and curriculum experts and school inspectors, were brought into the partnership as classroom-based Knowledge Building communities were new on the innovation agenda. Classroom teachers and students began to inquire into issues related to cultural diversity and sustainable development. Teacher educators, school principals, teachers, students, and other experts learned the Knowledge Building principles from Knowledge Society Network members and from one another at almost the same time. The Department of Education brought in its' own expertise through the participation of knowledgeable officers. Some participants became quite knowledgeable in the domain.

\section{Multi-level, research-based innovation}


These school-university-government research partnerships worked as living organisms by helping each other through this innovative process and its documentation. Each researcher was assigned to a school to assess onsite practices during the first year. Researchers and their assistants were from the University of Barcelona and the University Autonome of Barcelona. Their role depended very much on each teacher's mastery with Knowledge Building principles, Knowledge Forum, and scaffolds, but researchers went from just answering basic questions (e.g., "What does it means to pose a "real problem"? "What scaffold supports would encourage students"?) to working through difficulties with the teachers as students pursued inquiries at increasingly deep levels. Throughout the researchers provided "just-in-time" help; and as well, their interest and involvement provided an extra motivation for the participating teachers. During the second year, this school-university-government partnership was more focused on specific schools as they reached new levels of mastery. However, the researchers' role remained one of low-key mentorship at select moments. Overall, teachers experienced researchers as helpful collaborators as they worked together to overcome concrete problems such as failed Internet connectivity, lack of computers, lack of enthusiasm, and so forth. Additionally, preservice teachers conducted their practica at these innovative schools, providing instruction while also lending support.

Partners also participated in face-to-face monthly meetings at the Department of Education (Catalunya, Spain) and have participated in bilingual sessions at the Summer Institute of the Institute for Knowledge Innovation and Technology (Toronto, August 2005-2009, see http://ikit.org/summerinstitutes.html), and in online sessions during which they were exposed to Knowledge Building practices and shared their own practices. Participants discussed, using Catalan as their language of communication, Knowledge Building practice within a professional development database linked to the Knowledge Society Network, and began posting online videos of their Knowledge Building practices. Translation has been offered to those speaking French or English. Participants presented their innovative works at a European-Mediterranean conference in November 2006, and a research evaluation report was submitted in December 2006 by the Consell Superior d'Avaluació at the authorities of the Department of Education (Catalunya). The initiative has been considered a success in terms of participants' interest and motivation, level of participation, relationships between participants, and quality of student work.

From 2006-2009 some classroom-based Knowledge Building communities engaged in international collaboration with classroom-based teams in Hong Kong, Quebec, Norway, and Mexico. Teachers demonstrate research-based innovation involving Knowledge Building principles and analysis of classroom pedagogy (e.g., community building, student work on authentic questions, idea improvement) and show results to other teachers, school principals, university professors, and government agents. Increasing numbers of school principals are offering orientation and support aligned with the Department of Education's initiative.

According to school principals' and teacher testimonials students continued to be motivated and to generate impressive work in these emerging Knowledge Building communities. Their artifacts (see, for instance, the video produced by Denayrolles, 2006) are exemplars for other 
innovators interested in launching their own Knowledge Building partnership (e.g., Norway, Puebla).

\section{Case Study Two}

\section{Knowledge Building as a shared vision}

The vision underlying the second case study was to address problems surrounding small rural schools. In these schools few students are enrolled and this often leads to lack of vitality, school closures, and occasionally to the loss of communities in Quebec. Laferrière proposed the idea of remote networked school to a project manager of a knowledge transfer firm, CEFRIO, that had been approached by a Department of Education officer for its expertise on information technology, social innovation, and for successful previous work with governmental agencies and local organizations. A remote networked school proposal was submitted by the firm to the Department of Education whose practice is to associate university researchers in the knowledge transfer process. The Deputy Minister of Education recognized the alignment of the proposal with set goals pertaining to innovative solutions for school success in small remote schools and pro-action about the survival of small villages in rural areas. Funding was secured, and school recruitment began.

In the pilot phase, three schools from three different school districts were selected. Local multipartner committees were established. Interest in the initiative was high, and partners were invited to be creative regarding its implementation. The idea of the remote networked school kept growing, and a Knowledge Building process unfolded as experiments were conducted, and early research results analyzed.

A number of knowledge transfer sessions were held to present these results, and illustrate what can happen in a remote network school when students work on authentic problems using Knowledge Forum and a videoconferencing system. For example, students in some remote villages had explored the implications of building power plants in their local environment (hydro-electric dams, nuclear complexes, or wind mills) in their community and became educated citizens engaged in community discourse.

\section{Symmetric knowledge advancement}

Before this work began volunteer teachers had heard neither of Knowledge Building nor Knowledge Forum. School students had made little use of Internet-based technologies during class time, and had experienced a rather traditional learning environment. School districts committed personnel to the initiative, including technology and pedagogy experts, but they were introduced to the new pedagogy and technology at almost the same time as school principals and teachers. Students' first contributions and knowledge advances helped them see new possibilities for enriching the classroom environment in a remote school.

Technology experts had come in with their own ideas about relevant technology together with their own competence in the use of some new technologies for designing the remote networked school in their own district. The adoption of the recommendations of university 
experts-iVisit ${ }^{\mathrm{TM}}$, a videoconferencing system for synchronous verbal communication, and Knowledge Forum for asynchronous communication and collaboration-meant that they were first to be trained in their use. University experts anchored their recommendation in the education reform that was underway, one that promoted constructivist pedagogies, and searched for and provided site-based evidence to indicate that their recommendations represented a viable plan.

A few districts and school-based participants are still not aware of Knowledge Building principles, but most now have some sense of this innovation and its positive results. The transfer/knowledge management firm brought in its own expertise in terms of project management and dissemination of results, and also advanced its own understanding of knowledge management through the ways teachers and students worked with knowledge.

\section{Multi-level, research-based innovation}

Graduate students and pre-service teachers from the three participating universities provided "just-in-time" mentoring to teachers through iVisit. Their interventions were primarily informed by analyses conducted with the Analytical Toolkit. These synchronous interactions enabled teachers to understand, for instance, how students working on authentic problems also increase literacy (reading, writing, multimedia; see also in the present issue Chuy, et al.; Gan, Scardamalia, Hong, \& Zhang; Sun, Zhang, \& Scardamalia). Participants, including teachers, presented their innovative practices at four knowledge-transfer sessions, each attended by over 125 educators and others interested in the results of the initiative. During the first sessions, presenters made much reference to Knowledge Forum and its basic scaffolds, but little reference to the Knowledge Building principles. As evidence of Knowledge Building activity mounted, more visibility was given to the principles underlying this social innovation. A few selected artifacts were translated into French or Catalan for their strategic value. Phase One's positive consensual results led to more funding for sustaining and scaling up the collective effort.

In Phase Two, the initiative expanded to 13 sites. Many face-to-face and online conversations led to a shared vision for the remote networked schools. Participants helped to introduce and invite others into newly adopted practices, including engaging students across the remote networked schools in posing authentic questions, developing students' ideas, and integrating the work of small classrooms from different schools so that more students could engage in the same inquiry. Teaming with another teacher from another school became the main pattern of cooperation. This represented a significant advance fostered by the technology as most of the teachers are the only ones in their school teaching a specific grade-and likely two or three different grades or subjects - so they experienced moving from an isolated to collaborative context for their work as a significant advance.

The consensus on Knowledge Forum as the appropriate technology to implement grew wider and stronger. Teachers of small remote schools established teaching dyads across schools for reflection on action. In one-third of the school districts, Knowledge Forum databases were created for collaborative reflection on action (pre- and post-action), and learning/knowledge- 
building artifacts made available to incoming teachers. Although research results were primarily compiled at the classroom level (student motivation, progressive discourse, reading comprehension, and academic progress), organizational change was also documented at the school and school district levels (time management, role distribution, new policies and routines) (Allaire et al., 2006).

Phase Three followed, and Phase Four is underway. Twelve sites (out of 13) decided to continue with the research and collaboration with university researchers and other partners in the design of remote networked schools, with the goal of bringing Knowledge Building pedagogy more fully into the classroom. Opportunities for multi-level innovation are plentiful as a provincial educational reform is underway. Regional offices of the Department of Education and schooldistrict superintendents have endorsed the remote networked school initiative. At the school district level, superintendents' leadership is visible through the ways they orient, fund, and coordinate the initiative within their organization. In Phase Three, ten more superintendents expressed interest in the initiative. And in Phase Four, four superintendents volunteered to institutionalize the innovation model in their school district. School principals' leadership is also called upon, and visible through their school planning, mission statement, redistribution of human and material resources, revision of school schedule to accommodate collaboration between schools, facilitation of task sharing and teamwork, and communications with parents, municipal leaders, and policy makers.

Regarding participation outside of Francophone Quebec, unilingual Francophone teachers/educators have very limited access to the full range of Knowledge Society Network participants and databases. However, with the advent of a new network of French-speaking participants from countries like Canada, Italy and Gabon there will be new opportunities for them to make valuable contributions and extend their work. In Quebec they discuss the integration of new technologies and effective uses in teaching and learning when they participate in regional or provincial gatherings, and as the network becomes increasingly multilingual there will be more opportunities for integration.

\section{Discussion}

Analyses from two case studies involving three-way school-university-government partnership confirmed the presence of three partnership dynamics: Knowledge Building as a shared vision, symmetric knowledge advancement, and multi-level, research-based innovation.

Characteristics and conditions were identified to support these partnership dynamics.

In both cases, Knowledge Building as a shared vision unfolded under the following conditions: Condition One-a three-way school-university-government partnership; Condition Twovertical/horizontal alignment of participants (presence of participants holding different but complementary positions in the educational structure); Condition Three-onsite and online activities to sustain engagement. Self-renewal was part of the agenda of each partner for both cases, and collaboration was manifest. In Case One, the Department of Education as a whole wanted a renewed approach to technology integration within schools, and the Oficina de Cooperacio Educativa I Cientifica International had a plan. In Case Two, the Department of 
Education wanted a new approach to the problem of equality of opportunity encountered by small remote schools, as the old approach had led to the closing of such schools and lack of vitality in small villages, if not their extinction. Government officers were not as active in Case Two as in Case One because they hired a knowledge-transfer agency to coordinate and manage the initiative. In Case Two, partners proceeded through iterative cycles-Phase One, Phase Two, Phase Three, Phase Four-that progressively emphasized Knowledge Building-whereas in Case One, partners focused more directly on Knowledge Building from the beginning, as a shared vision for classroom innovation or renewal. Verticality of concern was manifest among government agents and school participants, and was reflected through progressive mastery of the Knowledge Forum affordances in urban learning environments, including the Knowledge Building principles. In Case Two, a Knowledge Building approach was applied to the very idea of the remote networked school as a solution to an authentic problem, that of the lack of vitality of rural remote small villages.

In both cases teachers were better able to integrate their work with government-mandated curriculum as they gained greater understanding of the connections between the use of Knowledge Building and Knowledge Forum and the mandated curriculum. In Case One, teachers first tried, for collaborative purposes between schools, to select a common topic that was not included in the curriculum. That was year one, but by year two they were engaging students in the selection of issues related to the school curriculum. In Case Two, teachers let their students engage in the exploration of peripheral problems at first but became increasingly able to integrate students' inquiries in ways more centrally related to the curriculum. In both cases, onsite and online Knowledge Building activities were supported by the Knowledge Forum suite of tools and by experts who provided technological and pedagogical support.

Symmetric knowledge advancement was embedded in the two following conditions for supporting cycles of innovation: engagement of several partners in a genuine process of adoption-implementation-research/refinement-institutionalization (Condition Four), and prioritization of authentic problems for engaging classroom students in Knowledge Building (Condition Five). These two conditions, along with those pertaining to the first dynamic, Knowledge Building as a shared vision, set the stage for effective use of Knowledge Building pedagogy and technology, not just by educators but also by school students. It also led to its effective use by partners working outside the classroom, as they interacted to address problems of understanding related to various aspects of the innovation process (adoptionimplementation-research/refinement-institutionalization).

Scaling up of the innovation has taken the form of further networking in both cases: in Case One, a new initiative is building on the results of the first one; in Case Two, the fourth phase is building on Phase Three results, which are, in turn, building on Phase Two and Phase One results. In both cases, there are participants who understood sustainability to mean the institutionalization of Knowledge Building as part of school learners' experiences. Symmetric knowledge advancement-on the part of government officers, teachers, school principals, curriculum and technology experts, superintendents and teacher educators-enabled them to jointly tackle the very problem of Knowledge Building as social innovation. Without such 
coordinated effort school students would not have had the opportunity of engaging in the study and themselves be engaged in the authentic problems they identified for Knowledge Building. In complementary manner, artifacts of the knowledge-building communities provided evidence that social innovation was taking place, allowing the different partners to continue to support these innovations.

Multi-level, research-based innovation, as exemplified by the Knowledge Building communities, was scaffolded in both cases by more experienced and knowledgeable onsite and online participants (legitimate peripheral participation: see Lave \& Wenger, 1991), thus providing a rich teacher learning context within which meaning could be negotiated and ways of understanding could emerge and evolve. Access to more experienced knowledge builders (Condition Six) was exemplified, for instance in Case Two, by a direct online connection to a distributed team through videoconferencing (an iVisit room), and by knowledge-transfer sessions during which teachers shared their experience and artifacts with newcomers to Knowledge Building. In Case One, teachers, researchers, and those in the Catalunyan government participated in synchronous virtual meetings with Canadian, Chinese, Italian, and Norwegian participants within the Knowledge Society Network. A teacher network, supportive of their own Knowledge Building (Condition Seven) was exemplified in online meetings. The meetings was held with the two following goals in mind: first, to describe progress in their Knowledge Building work, and second, to provide opportunities for Catalan participants to deepen their understanding of how to enact Knowledge Building principles in their classrooms. One striking example concerned how and whether students were able to use the "My Theory" scaffold support. Some thought that the term "my theory" should be used only in scientific contexts, others thought that "argument with evidence" was more familiar to students; others thought that maybe the terms "idea" or "opinion" would be more appropriate. From the Knowledge Building perspective (Scardamalia \& Bereiter, 2003), all ideas are to be treated as improvable-see the principle "Improvable Ideas" (Scardamalia \& Bereiter, present issue). Moreover, another Knowledge Building principle, the democratization of knowledge, emphasizes that theorizing is not restricted to a discrete few. Through engaging in discussions of theory development, among themselves, with their students, with research and scientific communities, new levels of meaning making at the conceptual and practical level were achieved.

These school-university-government partnerships worked like living organisms, each part helping out the other through the process. University researchers worked onsite and online, and conducted teaching and research activities. Their role depended very much on a particular school's goals, and mastery of the Knowledge Building principles and the Knowledge Forum suite of tools. Governments were highly instrumental in providing orientation and resources.

\section{Conclusion}

The above dynamics, characteristics, and conditions of partnerships for Knowledge Building constitute an emerging model. This model is more than a co-operative one (see Krishner, Dickinson, \& Blosser, 1996): participants' interaction evolved, in both cases, toward 
collaboration. When contributing to one another's understanding of the innovation at stake, participants' interaction was that of a Knowledge Building community.

The next level of innovation might be to involve students in the authentic problems for which technology integration seemed a favorable solution for government and university researchers. Could students work with teachers to address the many problems faced by remote and rural schools and to develop a close connection between the use of Internet-based technologies and the curriculum? Multi-level innovation could include students' designs for curricula that address socio-political issues around declining populations in remote and rural regions in Canada.

Colleagues from IberoAmericana University (Puebla, Mexico) involved teachers and students in two recent events (a workshop and a colloquium) aimed at understanding Knowledge Building as an epistemology and a methodology and engaging two high schools in Knowledge Building. From what we witnessed onsite, the dynamics and conditions identified above were being established. Moreover, the university as a partner is reinforced by the very fact that the Faculty of Education is involved and also the university as a whole: The University Rector has been supporting and funding the Knowledge Building initiative. Likely, their experience will contribute to the understanding of Knowledge Building partnerships.

\section{Acknowledgements}

The authors are grateful to the Catalunya and Quebec Departments of Education for the funding of this research.

\section{References}

Allaire, S., Beaudoin, J., Breuleux, A., Hamel, C., Inchauspé, P., Laferrière, T., \& Turcotte, S. (2006). L'école éloignée en réseau. Rapport de recherche, phase II, CEFRIO, Québec. Retrieved November 2009, from http://www.eer.qc.ca/publications.php

Banathy, B. H. (1991). Systems design of education: A journey to create the future. Englewood Cliffs, NJ: Educational Technology Publications.

Bates, A.W. (2000). Managing technological change: strategies for college and university leaders. San Francisco, CA: Jossey-Bass Publishers. Retrieved November 2003, from http://media.wiley.com/product_data/excerpt/18/07879468/0787946818.pdf

Becker, H. J., \& Riel, M. (1999). Teacher professionalism, school work culture and the emergence of constructivist-compatible pedagogies. Paper presented at the American Educational Research Association, Montreal. [Online]. Retrieved November 2001, from http://www.crito.uci.edu/tlc/findings/special_report2/start-page.htm

Bereiter, C. (2002). Education and mind in the knowledge age. Mahwah, NJ: Lawrence Erlbaum Associates Publishers. 
Bereiter, C., \& Scardamalia, M. (1989). Intentional learning as a goal of instruction. In L. B. Resnick (Ed.), Knowing, learning, and instruction: Essays in honor of Robert Glaser (pp. 361-392). Hillsdale, NJ: Erlbaum.

Bereiter, C., \& Scardamalia, M. (1993). Surpassing ourselves: An inquiry into the nature and implications of expertise. Chicago, IL: Open Court.

Breuleux, A., Erickson, G., Laferrière, T., \& Lamon, M. (2002). Devis sociotechniques pour l'établissement de communautés d'apprentissage en réseau: Principes de conception et conditions de réussite résultant de plusieurs cycles d'intégration pédagogique des TIC / Building networked learning communities: Design principles and the conditions for successful pedagogical integration of ICTs in teacher education. Revue des sciences de l'éducation, 28(2), 411-434.

Bringle, R. G., \& Hatcher, J. A. (2002). Campus-Community partnerships: The terms of engagement. Journal of Social Issues, 58(3), 503-516.

Bullough, R. V., Birrell, J. R., Young, J., Cecil Clark, D., Erickson, L., Earle, R. S., Campbell, J. F., Hansen, L., \& Wiston Egan, M. (1999). Paradise unrealized: Teacher educators and the costs and benefits of school/university partnerships. Journal of Teacher Education, 50(5), 381-390.

Chuy, M., Scardamalia, M., Bereiter, C., Prinsen, F., Resendes, M., Messina, R., Hunsburger, W., \& Teplovs, C. (2010). Understanding the nature of science and scientific progress: A theory-building approach. Canadian Journal of Learning and Technology, 36(1).

Clark, R. W. (1999). Effective professional development schools. Agenda for education in a democracy (Vol 3). San Francisco, CA: Jossey-Bass Publishers.

Consell Superior d'Avaluacio. (2006). Avaluacio del projecte COMconèixer: L'aprenentatge a través de comunitats virtuals, Document 8. Barcelona: Departament d'Educacio, Generalitat de Catalunya.

Croteau-Bouffard, M.-H. (2007). La progression de l'explication dans l'investigation collective d'une problématique sociale à l'écrit par des élèves du secondaire. (Thèse de maîtrise). Université Laval.

Denayrolles, N. (2006). Una experiencia international de coelaboracio de coneixement: Aprendre a construir junts el nostre coneixement. Video document. Barcelona: Direccio General d'Ordenacio i Innovacio Educativa Oficina de Cooperacio Educativa I Cientifica International, Departament d'Educacio, Generalitat de Catalunya.

Ertmer, P. A., \& Hruskovy, C. (1999). Impacts of a University-elementary school partnership designed to support technology integration. ETR\&D, 47(1), 81-96.

Fishman, B., Marx, R. W., Blumenfeld, P., \& Krajcik, J. (2004). Creating a framework for research on systemic technology innovations. The Journal of the Learning Sciences, 13(1), 43-76. 
Fullan, M. (2000). The three stories of education reform. Phi Delta Kappan, 81(8), 581-584.

Gan, Y. C., Scardamalia, M., Hong, H. Y., \& Zhang, J. (2010). Making thinking visible: Growth in graphical literacy, Grades 3 to 4. Canadian Journal of Learning and Technology, 36(1).

Generalitat de Catalunya, Departament d'Educacio, Oficina de Cooperacio Educativa I Cientifica International (2005). Unpublished document, p. 2.

Goodlad, J. I. (1990). Teachers for our nation's schools. San Francisco: Jossey-Bass.

Hartnell-Young, E. (2009). Learning for teaching: Building professional knowledge on a national scale. Canadian Journal of Learning and Technology, 35(1), Online:

http://www.cjlt.ca/index.php/cjlt/article/view/516

Holmes Group. (1990). Tomorrow's schools: A report of the Holmes Group. East Lansing, MI: The Holmes Group.

Hong, H. Y., Scardamalia, M., \& Zhang, J. (2010). Knowledge Society Network: Toward a dynamic, sustained network for building knowledge. Canadian Journal of Learning and Technology, 36(1).

Kenny, J. (2003). A research based model for managing strategic educational change and innovation projects. Research and development in higher education, Volume. 26. Proceedings of HERDSA conference, Christchurch New Zealand (pp. 333-342). Retrieved June 2010, from

http://www.google.ca/url?sa=t\&source=web\&cd=1\&ved=0CBQQFjAA\&url=http\%3A\%2F\% 2Fciteseerx.ist.psu.edu\%2Fviewdoc\%2Fdownload\%3Fdoi\%3D10.1.1.107.7612\%26rep\%3Dr ep1\%26type\%3Dpdf\&ei=EwgSTLuIN8LflgezpKmLCQ\&usg=AFQjCNGI_JAr1SzA4nlo0jR7ouox dAqLbg

Koschmann, T. D. (1993/1994). Computer support for collaborative learning. Journal of the Learning Sciences, 3(3), 2109-225.

Krishner, B. W., Dickinson, R., \& Blosser, C. (1996). From cooperation to collaboration: The changing culture of a school/university partnership. Theory into Practice, 35(3), 205-213.

Laferrière, T. (2003). IKIT Virtual Tours. Retrieved from http://ikit.org/mvt/pd.html

Laferrière, T., Breuleux, A., \& Erickson, G. (2007). Innovative models of web-supported university-school partnerships. Canadian Journal of Education, 30(1), 211-238.

Laferrière, T., Lamon, M., \& Allaire, S. (2005, April). Virtual practica in K-12 innovative classroom settings: A time management option? Paper presented at the Annual Meeting of the American Educational Research Association (AERA), Montreal. 
Lamon, M., \& Laferrière, T. (2004, June). Taking pre-service teachers on the Knowledge Building path. Paper presented at the Symposium Teaching at the cutting edge of inquiry.

Motivation, learning, and Knowledge Building in the $21^{\text {st }}$ century. Conference June 18-21, Stockholm, Visby, Tallinn.

Lamon, M., Laferrière, T., \& Scardamalia, M. (2005, April). Teaching expertise as progressive problem solving. Paper presented at the Annual Meeting of the American Educational Research Association (AERA), Montreal.

Lave, J., \& Wenger, E. (1991). Situated learning: Legitimate peripheral participation. Cambridge, UK: Cambridge University Press.

Legters, N., Balfanz, R., \& McPartland, J. (2002). Solutions for failing high schools: Converging visions and promising models. Retrieved November 2005, from http://www.ed.gov/about/offices/list/ovae/pi/hs/legters.doc

Levine, M., \& Trachtman, R. (Eds.) (1997). Making professional development schools work: Politics, practice, and policy. New York: Teachers College Press.

McAuley, A. (2009). Knowledge Building in an aboriginal context. Canadian Journal Of Learning And Technology / La Revue Canadienne De L'Apprentissage Et De La Technologie, 35(1). Retrieved June 11, 2010, from http://www.cjlt.ca/index.php/cjlt/article/view/514/244

McBee, R.H., \& Moss, J. (2002). PDS partnerships come of age. Educational Leadership, 59(6), 61-64.

Moustakas, C. (1990). Heuristic research: Design, methodology and applications. London: Sage.

National Council for Accreditation of Teacher Education [NCATE]. (2001). Standards for professional development schools. Retrieved January 2006, from http://www.ncate.org/documents/pdsStandards.pdf

Organization for Economic Co-operation and Development [OECD]. (2006). Are students ready for a technologically-rich world: What PISA studies tell us. Paris: Author.

Resta, P. (Ed.) (in press). Teacher development in an e-learning age: A policy and planning guide. Paris: UNESCO.

Sandholtz, J. H. (2002). Inservice training or professional development: contrasting opportunities in a school/university partnership. Teaching and Teacher Education, 18(7) 815-830.

Scardamalia, M. (2002). Collective cognitive responsibility for the advancement of knowledge. In B. Smith (Ed.), Liberal education in a knowledge society (pp. 67-98). Chicago: Open Court. 
Scardamalia, M. (2003). Knowledge Society Network (KSN): Toward an expert society for democratizing knowledge. Journal of Distance Education, 17(Suppl. 3, Learning Technology Innovation in Canada), 63-66. http://ikit.org/fulltext/2003_TheKSN.htm

Scardamalia, M., \& Bereiter, C. (1996). Engaging students in a Knowledge Society. Educational Leadership, 54(3), 6-10.

Scardamalia, M., \& Bereiter, C. (2003). Knowledge Building. In Encyclopedia of Education, second edition (pp. 1370-1373). New York: Macmillan Reference.

Scardamalia, M., \& Bereiter, C. (2006). Knowledge Building: Theory, pedagogy, and technology. In R. Sawyer (Ed.), The Cambridge handbook of the learning sciences (pp. 97-117). Cambridge, UK: Cambridge University Press.

Scardamalia, M., \& Bereiter, C. (2010). A brief history of Knowledge Building. Canadian Journal of Learning and Technology, 36(1).

Scardamalia, M., Bransford, J., Kozma, R., \& Quellmalz, E. (in press). New assessments and environments for Knowledge Building. Assessment and Learning of 21st Century Skills. Paper posted to http://www.atc21s.org/home/

Strauss, A. L., \& Corbin, J. (1998). Basics of qualitative research: Techniques and procedures for developing grounded theory (2nd ed.) Thousand Oaks, CA: Sage.

Sun, Y., Zhang, J., \& Scardamalia, M. (2010). Developing deep understanding and literacy while addressing a gender-based literacy gap. Canadian Journal of Learning and Technology, 36(1).

Sykes, G. (1997). Worthy of the name: Standards for professional development schools. In Levine, M., \& Trachtman, R. (Eds.), Making professional development schools work: Politics, practice, and policy (pp. 159-181). New York, NY: Teachers College Press.

Teitel, L. (1997). Changing teacher education through professional development school partnerships: five-year follow-up study. Teachers College Record, 99(2), 311-334.

Teitel, L. (2001). An assessment framework for professional development schools: Going beyond the leap of faith. Journal of Teacher Education, 52(1), 57-69.

UNESCO. (2003). Information and communication technologies in teacher education. Paris: Author.

UNESCO (2008). ICT competency standards for teachers. Retrieved June 2009, from http://portal.unesco.org/ci/en/ev.phpURL_ID=25740\&URL_DO=DO_TOPIC\&URL_SECTION=201.html 